\title{
Biodiversity of zooplankton communities in the Upper Paraná River floodplain: interannual variation from long-term studies
}

\author{
Lansac-Tôha, FA.*, Bonecker, CC., Velho, LFM., \\ Simões, NR., Dias, JD., Alves, GM. and Takahashi, EM. \\ Pós-graduação em ecologia de ambientes aquáticos continentais - PEA, \\ Departamento de Biologia - DBI, Nupélia, Universidade Estadual de Maringá - UEM, \\ Av. Colombo, 5790, CEP 87020-900, Paraná, PR, Brazil \\ *e-mail: fabio@nupelia.uem.br \\ Received November 10, 2008 - Accepted May 4, 2009 - Distributed 30 June, 2009
}

(With 6 figures)

\begin{abstract}
We investigated the effect of interannual variation of hydrosedimentological regime and connectivity on the zooplankton biodiversity in the Upper Paraná River floodplain. Zooplankton samplings were undertaken between 2000 and 2007, in different environments of the floodplain, including connected and isolated floodplain lakes, backwaters, rivers and channels. The zooplankton included 541 species. Rotifers showed the highest species richness and abundance. Among the zooplankton species, 71 represent new occurrence records for the floodplain. The species accumulation curve showed a continuous increase in gamma diversity, demonstrating the importance of long-term research for accurate knowledge of biodiversity in heterogeneous and dynamic ecosystems, such as the floodplains. Interannual beta diversity among studied years indicated a lesser alteration in community composition in 2001, when a long limnophase period was observed. In most of the environments, the highest species richness values were related to the greatest flooding amplitudes. Flooding amplitude, which is associated with connectivity, favors faunal exchange amongst the environments and between the pelagic and littoral zones. This explains the occurrence of both planktonic and non-planktonic species within the community. On the other hand, mean zooplankton abundance values were higher when a long isolation period occurred. Differences between the potamophase and limnophase amplitude associated with connectivity among the environments were the most important factors for the structure and dynamics of the zooplankton community in the Upper Paraná River floodplain.
\end{abstract}

Keywords: zooplankton, biodiversity, connectivity, interannual variation, floodplain.

\section{Biodiversidade de comunidades de zooplâncton na planície de inundação do Alto Rio Paraná: variações interanuais em estudos de longa duração}

\begin{abstract}
Resumo
O objetivo deste trabalho foi investigar o efeito da variação plurianual do regime hidrosedimentológico e da conectividade sobre a biodiversidade zooplanctônica da planície de inundação do Alto Rio Paraná. As amostragens do zooplâncton foram realizadas entre os anos de 2000 a 2007, em distintos ambientes dessa planície de inundação, incluindo lagoas abertas, lagoas fechadas, ressacos, rios e canais. A comunidade zooplanctônica foi constituída por 541 espécies, sendo os rotíferos o grupo mais especioso e abundante. Dentre essas espécies, 71 representam novas ocorrências para a planície de inundação. A curva de acumulação de espécies mostrou um incremento continuo da diversidade gama evidenciando a importância de estudos de longa duração para o conhecimento da real biodiversidade em ecossistemas heterogêneos e dinâmicos, como são as planícies de inundação. Os resultados da diversidade beta entre os anos estudados mostraram uma menor alteração da composição da comunidade em 2001, quando foi observado um longo período de limnofase. A maior riqueza média de espécies foi associada à grande amplitude de alagamento na maioria dos ambientes. A duração da inundação, associada à conectividade, favorece o intercâmbio de fauna entre os ambientes, bem como entre as regiões pelágica e litorânea, propiciando a ocorrência de espécies planctônicas e não planctônicas na comunidade. Por outro lado, a abundância da comunidade zooplanctônica foi maior quando ocorreu um extenso período de isolamento. Diferenças entre a amplitude de potamofase e a limnofase associada à conectividade entre os ambientes foram fatores preponderantes para estruturação e dinâmica da comunidade zooplanctônica na planície de Inundação do Alto Rio Paraná.
\end{abstract}

Palavras-chave: zooplâncton, biodiversidade, conectividade, variação interanual, planície de inundação. 


\section{Introduction}

Floodplains form a complex gradient between the river channel and uplands, within which a variety of secondary and tertiary ecotones is embedded (Ward et al., 1999). These systems are characterized by a remarkable environmental heterogeneity produced by complex interactions between surface water, groundwater and riparian systems, resulting in high biodiversity (Ward and Tockner, 2001). The hydrosedimentological regime, characterized by two phases (potamophase and limnophase), is the main factor driving the material and energy flow as well as the organization of aquatic communities in such ecosystems (Neiff, 1990; Junk et al., 1989). Moreover, the degree of connectivity of floodplain lakes to the main rivers has also gained attention as an important controlling factor in structuring aquatic communities in floodplain systems (Tockner et al., 1998; Ward et al., 1999; Bini et al., 2003; Velho et al., 2003; Alves et al., 2005; Thomaz et al., 2007; José de Paggi and Paggi, 2008; Bonecker et al., 2009).

Nevertheless, studies have shown remarkable interannual alterations influenced by climatic oscillations such as El Niño and La Niña (Bovo-Scomparin and Train, 2008), which determine anomalous periods in the hydrological dynamics of floodplain systems (Zalocar de Domitrovic et al., 2007). These climatic oscillations affect the frequency, intensity, tension, recurrence, amplitude and seasonality (FITRAS) of the water pulse (Neiff, 1990; 2001), and consequently, the degree of connectivity among floodplain biotopes.

Several studies have investigated the effects of one annual cycle on the structure and dynamics of the aquatic community in the Paraná River floodplain (Lansac-Tôha et al., 2004a, b; Rodrigues and Bicudo, 2004; Train et al., 2004; Agostinho et al., 2004a); however, few have shown the effect of interannual variation on the community's abundance and diversity (Zalocar de Domitrovic et al., 2007; Agostinho et al., 2004b; Bovo-Scomparin and Train, 2008; Rodrigues et al, 2009).

The goal of the present study was to investigate the effect of the interannual variation of hydrosedimentological regime and connectivity on the zooplankton biodiversity in the Upper Paraná River floodplain. This floodplain site is site six within the Brazilian PELD network of LTER (Long Term Ecological Research) sites.

\section{Material and Methods}

\subsection{Sampling design}

Zooplankton samplings were performed every three months between 2000 and 2007, except in 2003, when only two samplings were made. During the first two years, the samplings were carried out in 36 environments from the Upper Paraná River floodplain (including connected and isolated floodplain lakes, backwaters, rivers and channels) in order to increase our knowledge of the zooplankton diversity, which is one of the main goals of the LTER. In later years, 12 of the original 36 environments were sampled to study the interannual community variation (Figure 1).

The zooplankton community was sampled at one sampling station for each environment, in the pelagic zone at subsurface, using a motorized pump and plankton net $(68 \mu \mathrm{m})$ to filter $1,000 \mathrm{~L}$ of water per sample. The material was preserved in solution of $4 \%$ formaldehyde buffered with calcium carbonate.

\subsection{Analysis of hydrological regime in the floodplain}

The daily hydrometric levels (in meters) of the Paraná and Ivinheima rivers (at Porto São José and Porto Sumeca stations, respectively) were supplied by Itaipu Binacional. The reference level was considered to be the hydrometric level of the main river at which the flooding in the floodplain began. This level was $3.5 \mathrm{~m}$ for the Paraná River, which floods the Paraná and Baía environments, and $2.7 \mathrm{~m}$ for the environments along the Ivinheima River (Rocha, 2002; Thomaz et al., 2004).

For each year, the following pulse attributes were estimated using the PULSO software (Neiff and Neiff 2003): i) limnophase amplitude (number of days that the hydrometric level remained below the reference level), ii) potamophase amplitude (number of days that the hydrometric level remained above the reference level) and iii) connectivity index among studied environments (ratio of the number of days under potamophase vs. limnophase) (Neiff, 1990).

Pulse attributes were evaluated separately for each river, since the hydrometric level of the Paraná River, from 1998 onwards, was strongly affected by operational procedures of the Porto Primavera impoundment. The Ivinheima River presents a more natural hydrological regime (Rocha, 2002).

\subsection{Analysis of community data}

Species were identified on lab slides under an optical microscope. For each sample, we identified the species until the species accumulation curve became stable. The individuals were identified using specialized taxonomic literature (Koste, 1978; Vucetich, 1973; Reid, 1985; Matsumura-Tundisi, 1986; Segers, 1995; Velho and Lansac-Tôha, 1996; Velho et al.; 1996; Elmoor-Loureiro, 1997; Lansac-Tôha et al., 2002).

Zooplankton abundance was determined using a Sedgewick-Rafter counting chamber under an optical microscope. At least 80 individuals were counted (Bottrel et al., 1976) in each of three sequential samples, which were obtained with a Hensen-Stempell pipette $(2.5 \mathrm{~mL})$.

Three components of species diversity were estimated: gamma diversity (regional species richness), alpha diversity (local species richness), and beta-2 diversity $\left(\beta_{2}\right)$ (index of alteration in the community composition in each year) (Harrison, 1992).

To estimate the gamma diversity, we used the results obtained from the samplings performed in all 36 environments over the study period. To compare the interan- 


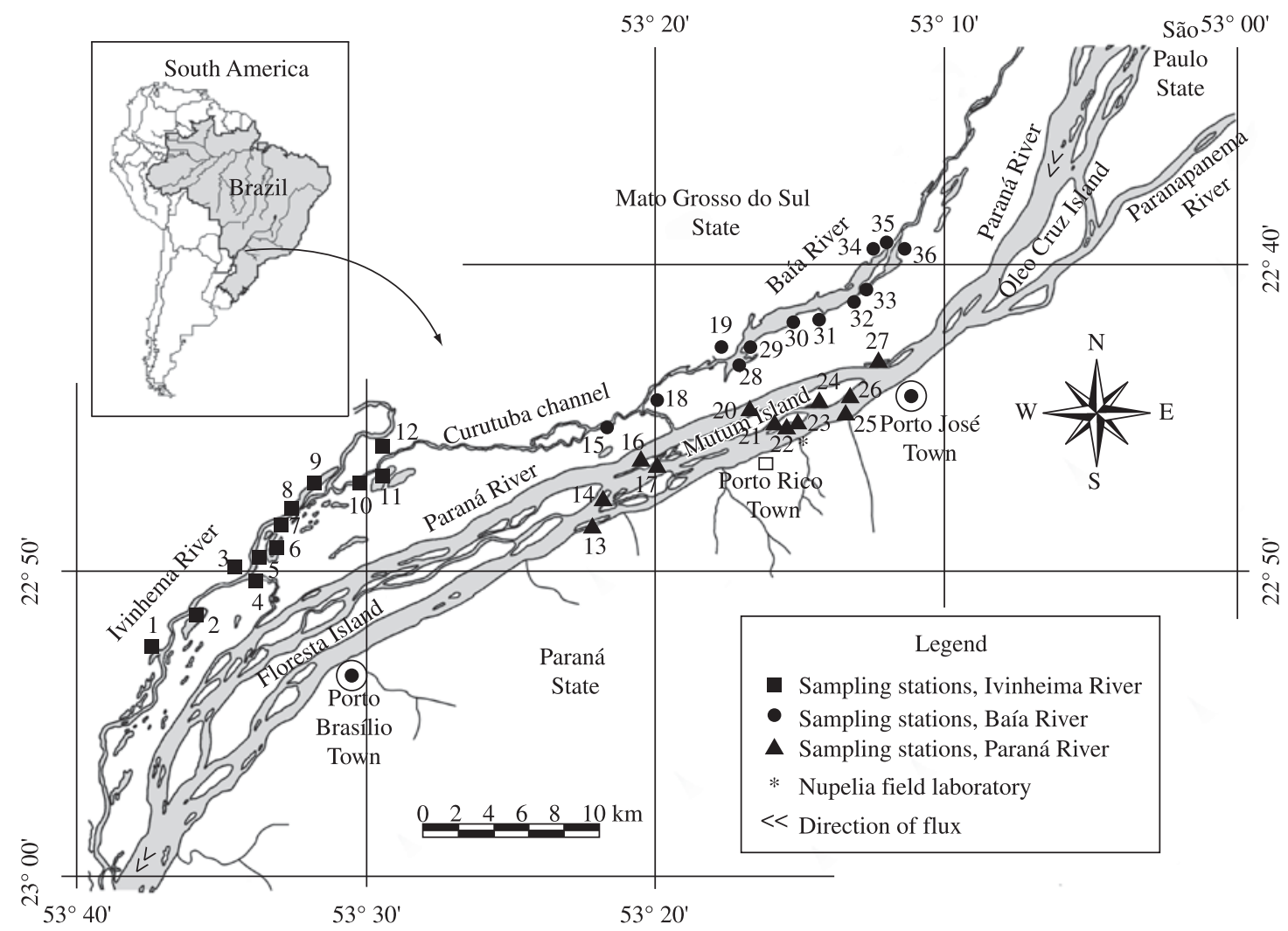

Figure 1. Study area and sampling stations in the Upper Paraná River floodplain. $1=$ Peroba floodplain lake; $2=$ Ventura floodplain lake; 3 = Zé do Paco floodplain lake; 4 = Ipoitã channel; 5 = Boca do Ipoitã floodplain lake; 6 = Patos floodplain lake; 7 = Capivara floodplain lake; 8 = Ivinheima river; 9 = Finado Raimundo floodplain lake; 10 = Jacaré floodplain lake; 11 = Sumida floodplain lake; 12 = Cervo floodplain lake; $13=$ Cortado channel; 14 = Pombas floodplain lake; $15=$ Curutuba channel; 16 = Manezinho backwater; 17 = Osmar floodplain lake; 18 = Traíra floodplain lake; 19 = Guaraná floodplain lake; 20 = Bilé backwater; 21 = Leopoldo backwater; 22 = Genipapo floodplain lake; 23 = Clara floodplain lake; 24 = Pau Véio backwater25 = Paraná river; 26 = Pousada floodplain lake; 27 = Garças floodplain lake; 28 = Baía river; 29 = Fechada floodplain lake; 30 = Pousada das Garças floodplain lake; 31 = Porcos floodplain lake; 32 = Aurélio floodplain lake; 33 = Baía channel; 34 = Maria Luiza floodplain lake; 35 = Gavião floodplain lake; 36 = Onça floodplain lake). All thirty-six environments were sampled in 2000 and 2001. Twelve $(2,4,6,8,15,17,19,24,25,27,28,29)$ were sampled from 2002 to 2007.

nual variation of species richness, alteration of community composition, and species' abundance, we used the results obtained from the twelve environments that were sampled in all eight years.

\subsection{Statistical analyses}

We used an Analysis of Variance (Sokal and Rolhf, 1981) to test interannual differences in mean species richness and abundance, including amplitude as a dummy variable with a value of either P (potamophase) or L (limnophase) for each sampling period. Pearson Correlation Analyses were performed between the number of days of the limnophase and potamophase amplitudes in each sampling period and the species richness and abundance of organisms. The abundance data were log transformed prior to analysis and the significance level adopted was $\mathrm{p}<0.05$. These analyses were carried out using Statistica software version 7.1 (Statsoft Inc., 2005).

\section{Results}

The flooding period in the Baía and Paraná systems (i.e., the number of days on which the hydrometric level was greater than the reference level of $3.5 \mathrm{~m}$ for the Paraná River) had a greater duration from 2005 to 2007 than in the other years. The isolation period (i.e., when the hydrometric level was less than the reference level of $3.5 \mathrm{~m}$ for the Paraná River) was longest in 2001. In the Ivinheima system, the lateral environments were subjected to a longer flooding period (i.e., when the hydrometric level was greater than the reference level of $2.7 \mathrm{~m}$ for the Ivinheima River) in 2001 and 2007, and to a longer isolation period (i.e., when the hydrometric level was less than the reference level of $2.7 \mathrm{~m}$ for the Ivinheima River) in 2002, 2003 and 2005 (Figure 2). Therefore, the index of connectivity amongst the lentic and lotic environments in each system was greater in 2005-2007 for 
the environments linked to the Paraná and Baía rivers, and was greater in 2001 and 2007 for those associated with the Ivinheima River (Table 1).

\subsection{Community species composition}

The zooplankton community was composed of 541 species; rotifers showed the highest species richness (304 species), followed by testate amoebae (120 species), cladocerans (74 species) and copepods (43 species). Among the zooplankton species, 71 are new occurrence records for the Upper Paraná River floodplain (29 rotifer species, 19 copepod species, 13 cladoceran species and 11 testate amoeba species) (Table 2).

Rotifers were represented by 27 families; the greatest richness was observed in the families Lecanidae (43 species), Trichocercidae (38 species), Notommatidae (36 species) and Brachionidae (35 species). The testate amoebae were distributed among 8 families, of which Difflugidae (62 species) was the most speciose. Among the microcrustaceans, cladocerans were represented by 7 families, of which Chydoridae (47 species) showed thw highest species richness, and copepods were represented by 24 Cyclopidae species and 19 Diaptomidae species (Figure 3).

The species accumulation curve showed a remarkable increase in the number of species recorded in the floodplain during the early years of the study (2000-2002). After this period, this increase was smaller, although there was still a trend of increasing number of species recorded in the floodplain (Figure 4).

\subsection{Beta diversity}

Data on the beta-2 diversity indicated that the turnover in species composition among the environments was greater in $2003(7.0 \%)$ and $2006(6.7 \%)$, and lower in $2001(3.4 \%)$. No significant relationship between beta- 2 diversity and species number was found (Figure 5).

During 2002, the greatest number of species (348) was recorded, and the change in community species composition among environments attained $4.7 \%$. In

Table 1. Pulse attributes of daily hydrometric levels of the Paraná and Ivinheima Rivers in the Upper Paraná River floodplain $(\mathrm{CI}=$ connectivity index, $\Sigma \mathrm{P}=$ number of days under potamophase, $\Sigma \mathrm{L}=$ number of days under limnophase) for each year of the study.

\begin{tabular}{ccccccccc}
\hline & \multicolumn{3}{c}{ Paraná River } & & \multicolumn{3}{c}{ Ivinheima River } \\
\cline { 2 - 3 } \cline { 7 - 8 } & $\Sigma \mathbf{P}$ & $\Sigma \mathbf{L}$ & $\mathbf{C I}$ & & $\Sigma \mathbf{P}$ & $\Sigma \mathbf{L}$ & $\mathbf{C I}$ \\
\hline 2000 & 27 & 339 & 0.08 & & 23 & 343 & 0.07 \\
2001 & 10 & 355 & 0.03 & & 60 & 305 & 0.20 \\
2002 & 51 & 314 & 0.16 & & 15 & 350 & 0.04 \\
2003 & 40 & 325 & 0.12 & & 7 & 358 & 0.02 \\
2004 & 25 & 341 & 0.07 & & 19 & 347 & 0.05 \\
2005 & 66 & 299 & 0.22 & & 42 & 323 & 0.13 \\
2006 & 88 & 277 & 0.32 & & 15 & 350 & 0.04 \\
2007 & 77 & 288 & 0.27 & & 52 & 313 & 0.17 \\
\hline
\end{tabular}

2001, the second largest number of species (255) was observed, but the change in zooplankton composition was low (3.4\%). During 2003 and 2006, when the community showed the greatest turnover among the environments, a similar level of species richness was found (220 and 223 species in 2003 and 2006, respectively).

\subsection{Species richness}

Species richness was greatest in the period from 2001 to 2003, when the highest variation in the number of species per sample (alpha diversity) was also observed. The maximum mean value of species richness was observed during 2002 (Figure 6).

Richness values were driven by the great contribution of rotifer and cladoceran species during the temporal variation in other groups. The lowest mean value of species richness was observed during 2000, when every group except the rotifers presented low values of species richness.

Significant differences in the species richness across hydrological periods $\left(\mathrm{F}_{(1,368)}=4.135 ; \mathrm{p}=0.043\right)$ were registered in each year. Species number showed a positive relationship with the potamophase amplitude and with the connectivity among the environments; the in-
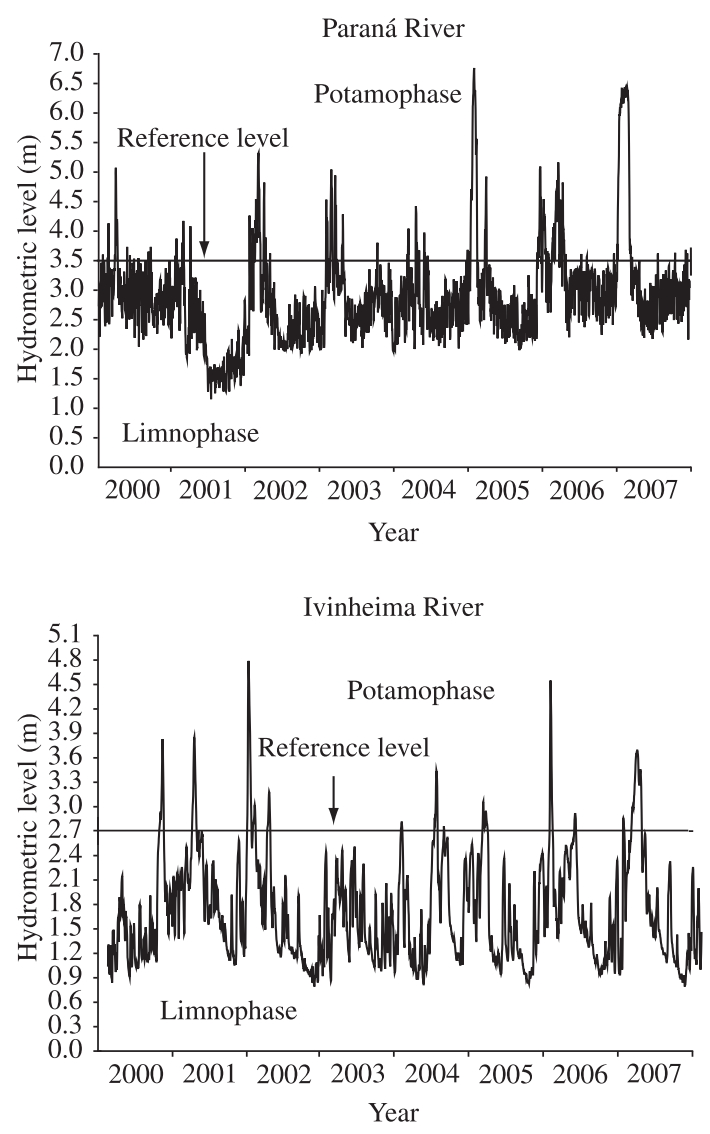

Figure 2. Daily hydrometric levels of the Paraná River and Ivinheima River during the period from 2000 to 2007. 
Table 2. New occurrence records of species found in plankton from 36 different environments (river, channel, backwater, connected and isolated floodplain lakes) from the Upper Paraná River floodplain, in the period from 2000 to 2007.

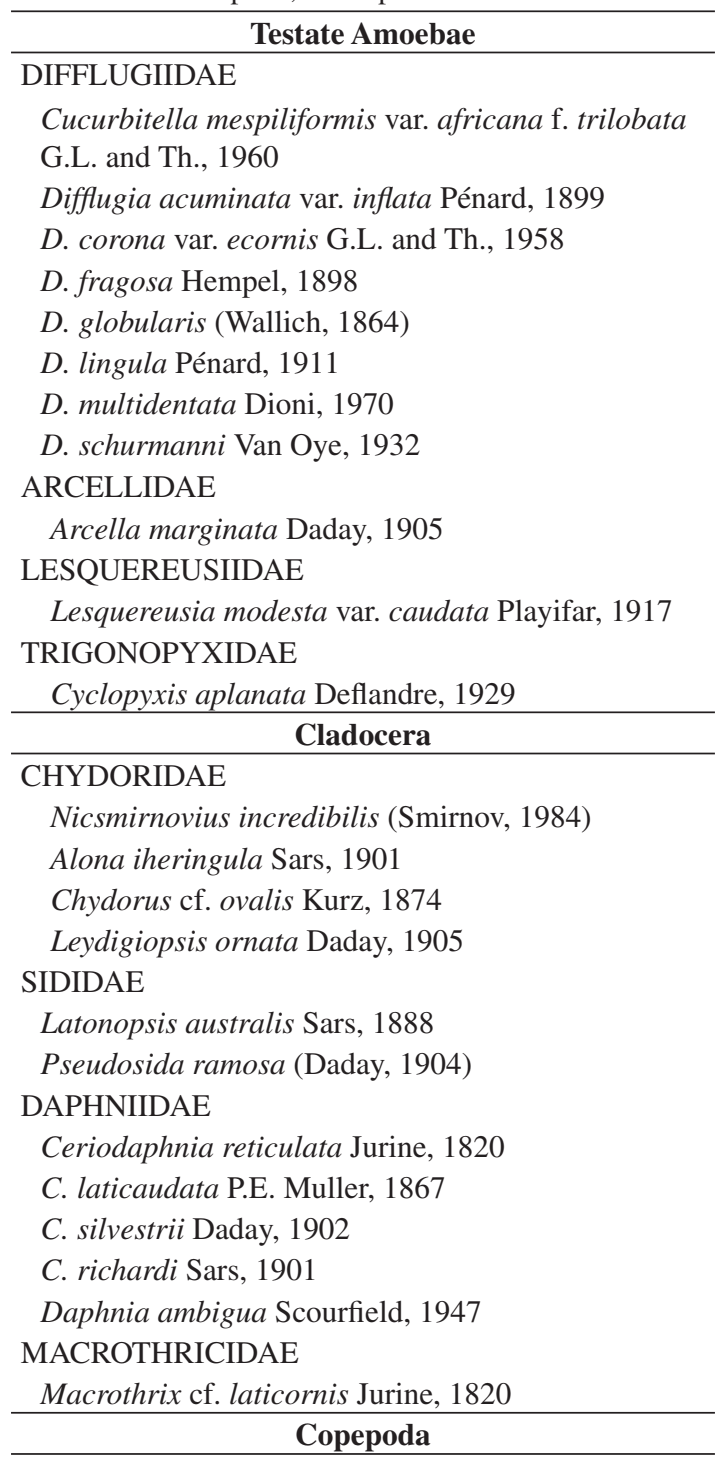

CYCLOPIDAE

Acanthocyclops robustus Sars, 1863

Eucyclops solitarius Herbst, 1959

E. elegans Herrick, 1884

Microcyclops alius (Kiefer, 1935)

M. ceibaensis (Marsh, 1919)

M. finitimus Dussart, 1984

Microcyclops sp.

Mesocyclops longisetus var. araucarus Loffler, 1961

Mesocyclops sp.

Metacyclops sp.

Paracyclops chiltoni (Thomson, 1882)

Tropocyclops prasinus (Fischer, 1860)

Thermocyclops inversus Kiefer, 1936
Table 2. Continued...

\section{DIAPTOMIDAE}

Notodiaptomus cearensis Wright, 1936

N. incompositus Pesta, 1927

$N$. cf. nordestinus (Wright, 1935)

N. paraensis (Dussart and Robertson, 1984)

N. conifer (Sars, 1901)

Odontodiaptomus paulistanus (Wright, 1936)

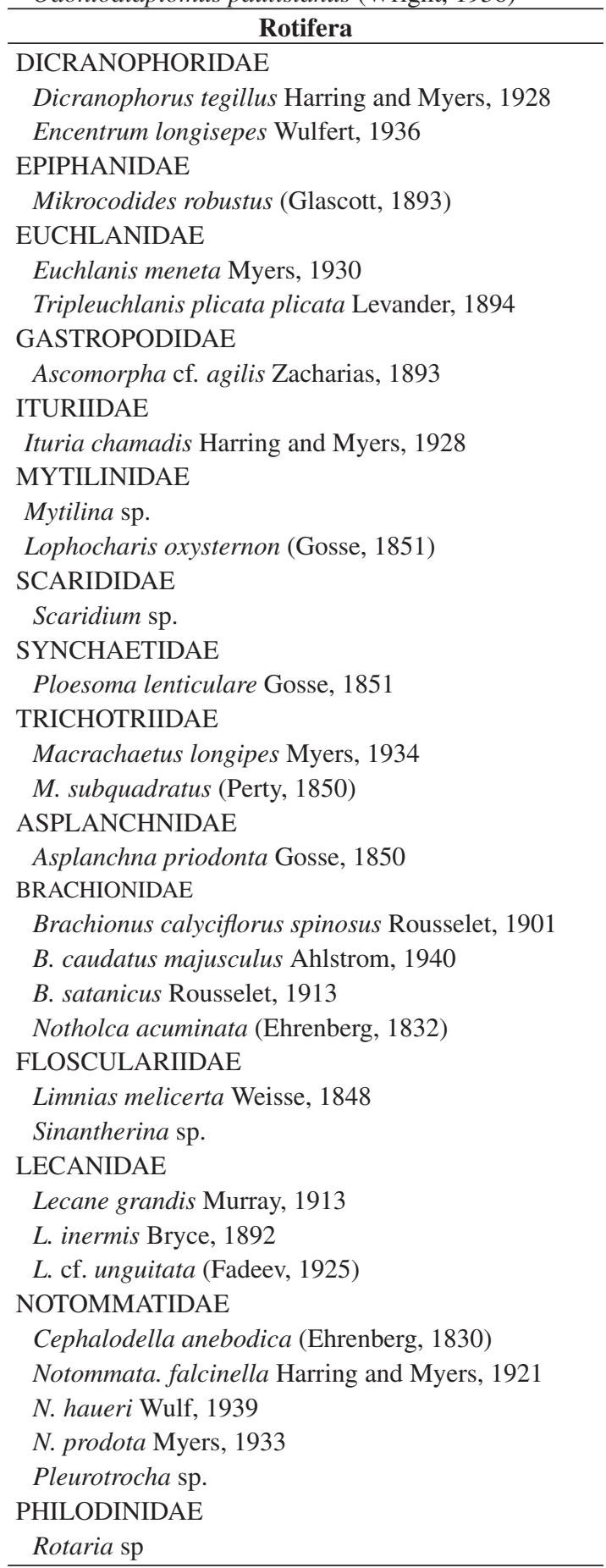



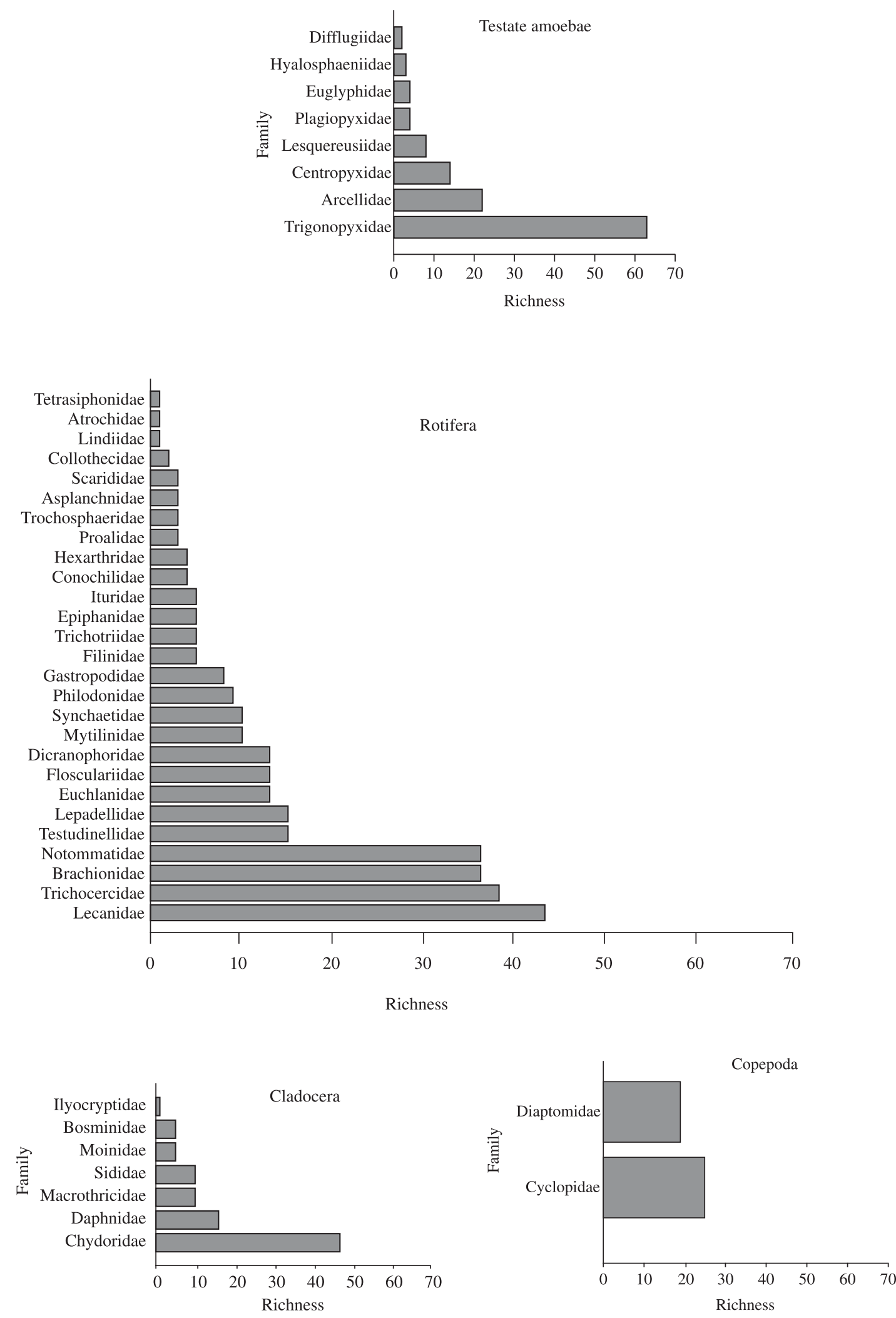

Figure 3. Number of species of each family of Testate Amoebae, Rotifers, Cladocerans and Copepods found in the Upper Paraná River Floodplain from 2000 to 2007. 


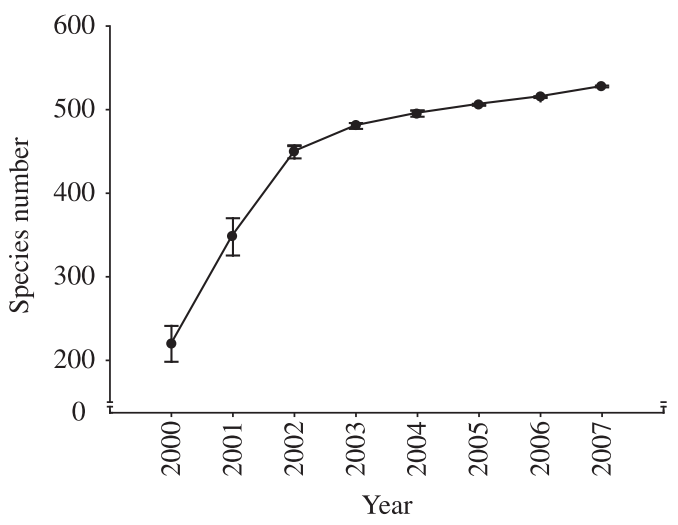

Figure 4. Species accumulation curve over the duration of the study.

verse was observed for the relationship between richness and limnophase amplitude and connectivity.

\subsection{Abundance}

The mean abundance values of the zooplankton community were highest during 2001 (Figure 6), when a long isolation period (355 days) was observed in most environments. However, no significant difference in temporal variation was found when comparing the number of individuals according to the amplitude of potamophase and limnophase. We found an inverse relationship between the number of individuals and the number of days under potamophase, and a direct relationship between the number of individuals and the number of days under limnophase. We also found a direct relationship between abundance and the connectivity index.

Rotifers and cladocerans contributed most to the total abundance of the zooplankton community, especially the rotifers in 2001 (Figure 6).

Cladoceran individuals showed high variation in abundance among the environments and sampling dates in 2004. The testate amoebae showed similar variation in 2007. Copepods were the least abundant group in the community (Figure 6); the cyclopids were numerically important in 2001, with high variation among the environments and sampling dates, and diaptomids were numerically important in 2003. Young stages (nauplii and copepodids) contributed most to copepod abundance.

\section{Discussion}

The estimated gamma diversity of the zooplankton community across all the floodplain environments is 541 species. Among these species, 71 are new occurrence records in the plankton of the Upper Paraná River floodplain, although 19 of these (six testate amoeba species, four rotifer species, five cladoceran species and four copepod species) have been recorded in other habitats in the floodplain (e.g. fauna associated with aquatic macrophytes) (Pereira, 2001; Lansac-Tôha et al., 2002;
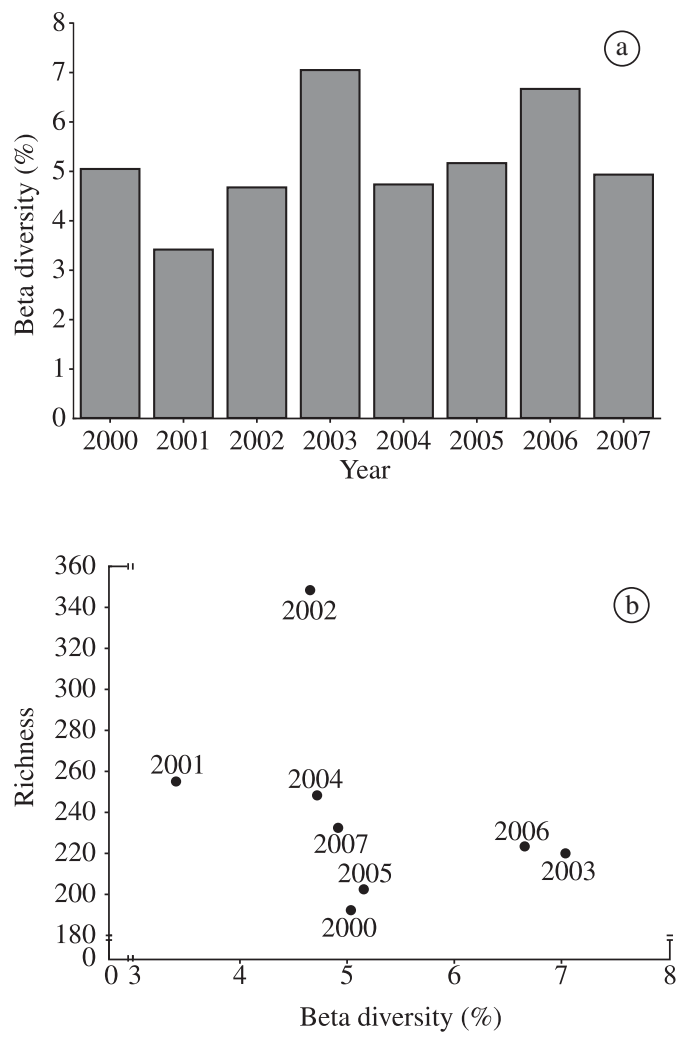

Figure 5. a) Beta diversity among the different environments of the Upper Paraná River floodplain from 2000 to 2007 and b) and the relationship of beta diversity to the total number of species recorded each year.

Fulone, 2008). Other studies have found an additional 54 species (Lansac-Tôha et al., 2004 a, b; Choueri et al., 2005; Joko et al., 2008), making a total of 595 identified species in plankton samples from the Upper Paraná River floodplain.

According to the species accumulation curve, the estimated gamma diversity in the floodplain will probably increase with sampling effort during long-term research (Agostinho et al., 2004a) on the interannual variation of the zooplankton composition in the distinct environments at this site.

Among the distinct zooplankton groups, rotifers contribute most to the community composition. Several surveys in floodplain environments in South America have shown that rotifers generally account for the highest species richness in zooplankton (Robertson and Hardy, 1984; Vásquez and Rey, 1989; Lansac-Tôha et al., 2004a; José de Paggi and Paggi, 2007).

The larger number of species in some families (Difflugiidae, Lecanidae, Trichocercidae, Chydoridae and Cyclopidae), contributing to the community gamma diversity, is typical of littoral zones, where there are extensive macrophyte stands frequently found in floodplains (Lansac-Tôha et al., 2004a) and other lentic environ- 

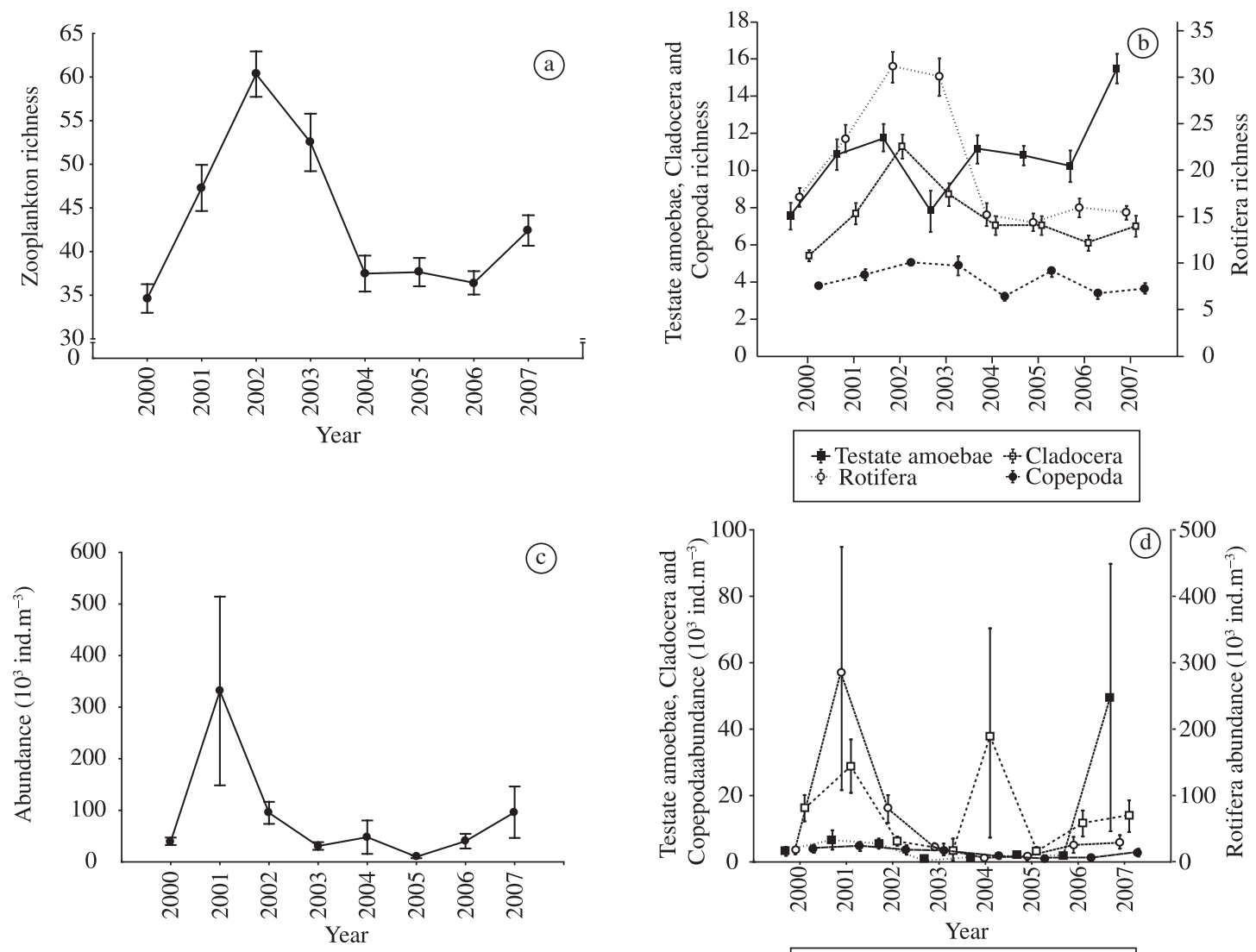

$\begin{array}{ll}\text { - Testate amoebae } & \text { Cladocera } \\ \text { - Rotifera } & \text { Copepoda }\end{array}$

Figure 6. a) Species richness of total zooplankton, b) species richness of the main taxonomic groups, c) abundance of total zooplankton and d) abundance of the main taxonomic groups in the Upper Paraná River floodplain from 2000 to 2007

ments (Santos-Wisniewski et al., 2002). Notommatidae, an important rotifer family in the Upper Paraná River floodplain, is rarely studied in tropical aquatic environments, mainly due to taxonomic difficulties (Aoyagui and Bonecker, 2004). Therefore, the 36 Notommatidae species that we found demonstrate the importance of taxonomic studies of rotifer biodiversity.

The beta diversity values indicate that lower connectivity may influence the maintenance of species composition in the various environments over the year. This was observed in 2001, when a long limnophase period (335 days) and low connectivity (0.028) among the environments were observed. A longer potamophase, which favors faunal exchange among the environments and consequently greater turnover in local community composition, was observed in 2003 and 2006.

Yearly differences in community species composition and potamophase and limnophase amplitude may also have influenced the species richness. During the dry years, the average number of species in each environment was greater (255 species in 2001), while in the years with shorter potamophase period, the species oc- currence was lower (223 species in 2003 and 220 species in 2006, respectively).

The highest mean species richness, recorded in 2002, was probably related to the great amplitude of flooding in most environments that year (51 days); on the other hand, in 2000, a lower number of species and a reduced flooding period (27 days) were recorded in the same environments, An intermediate value of the connectivity index (0.162) was also found in 2000. As previously discussed, a greater flood amplitude and higher connectivity favored the exchange of fauna among the environments, as well as between the pelagic and littoral zones within each environment.

The increase in species richness of plankton samples during periods of elevated hydrometrical level was related to i) increases in the number of available habitats due to flooding in the várzea, ii) incorporation of benthic and periphytic species in the pelagic community by the washing-out effect, and iii) the contribution of species coming from other environments that are isolated during the limnophase (Lansac-Toha et al., 2004b). 
The relationship between the significant differences in mean species richness and the number of days under potamophase and limnophase recorded each year suggests that the greater the amplitude of the former phase, the greater will be the species richness in the community. The observed relationships among species richness, hydrological phase and connectivity point out the importance of these attributes of the hydrosedimentological regime to the increase in species richness. We emphasize that among the studied environments, the connected floodplain lakes and the rivers to which they are connected present greater mean species richness values. These results have also been observed for rotifers and cladocerans in environments from this floodplain (Aoyagui and Bonecker, 2004; Alves et al., 2005), highlighting the importance of connectivity and the potamophase period to the species richness of these groups. The rise in the water level causes more extensive connections between environments, leading to greater faunal homogenization (Bozelli and Esteves, 1995; Lansac-Tôha et al., 2004a; José de Paggi and Paggi, 2007). Ward et al. (1999) have suggested that the connectivity among environments may be one of the main factors in the structure of aquatic communities, and is of paramount importance to the maintenance of biodiversity in this system.

The greater mean abundances of zooplankton recorded during 2001 are related to the absence of a dilution effect, as indicated by the lengthy limnophase period (355 days) in that year. Similar results have been found in other floodplain environments (Brandorff and Andrade, 1978; Espíndola et al., 1996; Bozelli, 2000; Lansac-Tôha et al., 2004a), and ascribed to the influence of the same hydrodynamic factor.

The greater variation in abundance among the environments and sampling dates in 2001 is related to the dynamics of the pulse regime in the different environments. The environments associated with the Ivinheima River experienced a longer flooding period (60 days) than did those associated with the Paraná and Baía rivers (10 days). In this way, the community went through two structuring processes: a dilution effect in the environments associated with the former river, and the absence of this effect in the environments associated with the latter two rivers. Meanwhile, greater abundance values were observed in the connected floodplain lakes associated with the Paraná and Baía rivers.

Greater values of zooplankton abundance are related to the numerical contribution of rotifers and cladocerans. Moreover, the former group was the most highly represented in the community. These results were verified, for example, in one connected floodplain lake associated with the Baía River. Furthermore, high values of phytoplankton biomass were recorded in this floodplain lake during the same period (Train et al., 2004), suggesting the importance of food resources in determining the abundance of zooplankton.

The great contribution of rotifers to the species richness and abundance of the zooplankton communi- ty may be due the opportunistic features of this group (Robertson and Hardy, 1984; Bozelli, 2000; Neves et al., 2003; Lansac-Tôha et al., 2004a; José de Paggi and Paggi, 2007), including their wide range of foods (from filamentous algae to bacteria) and high turnover rate, which makes it possible for them to colonize even unstable environments (Allan, 1976).

\section{Final Considerations}

Soon after the Porto Primavera impoundment (2000), the zooplankton community presented low values of species richness and abundance. In the period between 2001 and 2003, the importance of potamophase amplitude for species richness, and of limnophase amplitude for the abundance of organisms, was recognized. Flooding during potamophase affects the exchange of fauna among the environments, and the absence of dilution during limnophase contributes to the increase in the number of organisms in each environment.

Therefore, differences in the number of days under potamophase and limnophase influence the connectivity among the environments throughout the year. The connectivity, in turn, influences the species richness, the abundance of organisms, and the turnover in community composition in every studied environment.

Acknowledgements - We thank MSc. Ciro Yoshio Joko, MSc. Leandro Junio Fulone, Ana Paula Capelari Fernandes, Deise de Morais Costa and Renata Morais dos Santos for help with the analyses. This research was supported by PELD (site 6)/CNPq and Nupélia/UEM.

\section{References}

AGOSTINHO, AA., THOMAZ, SM. and GOMES, LC., 2004a. Threats for biodiversity in the floodplain of the Upper Paraná River: effects of hydrological regulation by dams. Ecohydrology \& Hydrobiology, vol. 4, no. 3, p. 255-268.

AGOSTINHO, AA., GOMES, LC., VERÍSSIMO, S. and OKADA, EK., 2004b. Flood regime, dam regulation and fish in the Upper Paraná River: effects on assemblage attributes, reproduction and recruitment. Reviews in Fish Biology and Fisheries, vol. 14, no. 1, p. 11-19.

ALVES, GM., VELHO, LFM., LANSAC-TÔHA, FA., ROBERTSON, B. and BONECKER, CC., 2005. Effect of the connectivity on the diversity and abundance of cladoceran assemblages in lagoons of the Upper Paraná River Floodplain. Acta Limnologica Brasiliensia, vol. 17, no. 3, p. 317-327.

AOYAGUI, ASM. and BONECKER, CC., 2004. Rotifers in different environments of the Upper Paraná River floodplain (Brazil): richness, abundance and the relationship with the connectivity. Hydrobiologia, vol. 522, p. 281-290.

BINI, LM., VELHO, LFM. and LANSAC-TÔHA, FA., 2003. The effect of connectivity on the relationship between local and regional species richness of testate amoebae (Protozoa, Rhizopoda) in floodplain lagoons of the Upper Paraná River, Brazil. Acta Oecologica, vol. 24, no. 1, p. 145-151.

BONECKER, CC., AOYAGUI, ASM. and SANTOS, RM., 2009. The impact of impoundment on the rotifer communities 
in two tropical floodplain environments: interannual pulse variations. Revista Brasileira de Biologia $=$ Brazilian Journal of Biology, vol. 69, no. (2 suppl), p. 529-537.

BOTTREL, HH., DUNCAN, A., GLIWICZ, Z., GRYGIEREK, E., HERZIG, A., HILLBRICHT-ILLKOWSKA, A., KURASAWA, H., LARSSON, P. and WEGLENSKA, T., 1976. A review of some problems in zooplankton production studies. Norwegian Journal of Zoology, vol. 24, no. 4, p. 419-456.

BOVO-SCOMPARIN, VM. and TRAIN, S., 2008. Long-Term variability of the phytoplankton community in an isolated floodplain lake of the Ivinheima River State Park, Brazil. Hydrobiologia, vol. 610, p. 331-344.

BOZELLI, RL. and ESTEVES, FA., 1995. Species diversity eveness and richness of the zooplankton community of Batata and Mussará lakes and of the Trombeta river, Amazonia, Brazil. In TIMOTIUS, KH. and GOELTENBOTH, F. (Eds.). Tropical Ecology: tropical lakes and reservoirs. Salatiga: Satia Wacana University Press. p. 89-110.

BOZELLI, RL., 2000. Zooplâncton. In BOZELLI, RL., ESTEVES, FA. and ROLAND, F. (Eds.). Lago Batata: impacto e recuperação de um ecossistema amazônico. Rio de Janeiro: IB-UFRJ; SBL. p. 119-138.

BRANDORFF, GO. and ANDRADE, ER., 1978. The relationship between the water level of the Amazon River and the fate of the zooplankton population in Lago Jacaretinga, a varzea lake in the central Amazon. Studies and Neotropical Fauna \& Environment, vol. 13, no. 2, p. 63-70.

CHOUERI, RB., BONECKER, CC. and DIAS, JD., 2005. Spatial and temporal density variation of microcrustacean assemblages in different systems of the upper Paraná river floodplain (PR/MS-Brazil). Acta Scientiarium. Biological Science, vol. 27, no. 3, p. 243-250.

ELMOOR-LOUREIRO, MAL., 1997. Manual de identificação de cladóceros límnicos do Brasil. Brasília: Ed. Universa. 155p.

ESPÍNDOLA, EG., MATSUMURA-TUNDISI, T. and MORENO, IH., 1996. Efeitos da dinâmica hidrobiológica do sistema Pantanal matogrossense sobre a estrutura da comunidade de zooplâncton da lagoa Albuquerque. Acta Limnologica Brasiliensia, vol. 8, no. 1, p. 37-57.

FULONE, LJ., 2008. Influência da complexidade estrutural de macrófitas aquáticas sobre a diversidade de organismos perifíticos. Maringá: Universidade Estadual de Maringá. 41p. Dissertação de Mestrado.

HARRISON, S., ROSS, SJ. and LAWTON, JH., 1992. Beta diversity on geographic gradients in Britain. Journal of Animal Ecology, vol. 61, no. 1, p. 151-158.

JOKO, CY., LANSAC-TÔHA, FA., MURAKAMI, EA. and BONECKER, CC., 2008. Novas ocorrências de Lecane no plâncton de distintos ambientes da planície de inundação do alto rio Paraná. Acta Scientiarium. Biological Science, vol. 30, no. 2, p. 165-171.

JOSÉ De PAGGI, SJ. and PAGGI, JC., 2007. Zooplankton. In IRIONDO, MH., PAGGI, JC. and PARMA, MJ. (Eds.). The Middle Paraná River: limnology of a subtropical Wetland. New York: Springer. p. 229-245

JOSÉ De PAGGI, SJ. and PAGGI, JC., 2008. Hydrological connectivity as a shaping force in the zooplankton community of two lakes in the Paraná River floodplain. International Review Hydrobiology, vol. 93, no. 6, p. 659-678.
JUNK, WJ., BAILEY, PB. and SPARKS, RE., 1989. The flood pulse concept in river-floodplain systems. Canadian Special Publication of Fisheries and Aquatic Sciences, vol. 106, p. 110-127.

KOSTE, W., 1978. Rotatoria die Rädertiere Mitteleuropas begründet von Max Voight. Monogononta. Berlin: Gebrüder Borntraeger. Vol. I (673p.) e Vol. II (474p.).

LANSAC-TÔHA, FA., VELHO, LFM., HIGUTI, J. and TAKAHASHI, EM., 2002. Cyclopidae (Crustacea, Copepoda) from the Upper Paraná River Floodplain, Brazil. Revista Brasileira de Biologia = Brazilian Journal of Biology, vol. 62, no. 1 , p. $125-133$.

LANSAC-TÔHA, FA., VELHO, LFM. and BONECKER, CC., 2004a. Composition, species richness and abundance of the zooplankton community. In THOMAZ, SM., AGOSTINHO, AA. and HAHN, NS. (Eds.). The Upper Paraná River and its floodplain: physical aspects, ecology and conservation. Leiden: Backhuys Publishers. p. 145-190.

LANSAC-TÔHA, FA., BONECKER, CC., VELHO, LFM., TAKAHASHI, EM. and NAGAE, MY., 2004b. Zooplankton in the upper Paraná river floodplain: composition, richness, abundance and relationships with the hydrological level and the connectivity. In AGOSTINHO, AA., RODRIGUES, L., GOMES, LC., THOMAZ, SM. and MIRANDA, LE. (Eds.). Structure and functioning of the Paraná river and its floodplain. Maringá: Eduem. p. 75-84.

MATSUMURA-TUNDISI, T., 1986. Latitudinal distribution of Calanoida copepods in freshwater aquatic systems of Brazil. Revista Brasileira de Biologia = Brazilian Journal of Biology, vol. 46, no. 3, p. 527-553

NEIFF, JJ., 1990. Ideas para la interpretación ecologica del Paraná. Interciencia, vol. 15, no. 6, p. 424-441.

2001. Diversity in some tropical wetland systems of South America. In GOPAL, B., JUNK, WJ. and DAVIS, JA. (Eds.). Biodiversity in wetland: assessment function and conservation. Leiden: Backhuys Publishers. p. 157-186.

NEIFF, JJ. and NEIFF, M., 2003. PULSO: software para análisis de fenómenos recurrentes. Buenos Aires: Dirección Nacional de Derecho de Autor $\mathrm{N}^{\circ}$. 236164. Available from: <http://www. neiff.com.ar>. Access in: 15 de Julho de 2008.

NEVES, IF., ROCHA, O., ROCHE, KF. and PINTO, AA., 2003. Zooplankton community structure of two marginal lakes of the river Cuiabá (Mato Grosso, Brazil) with a analysis of Rotifera and Cladocera diversity. Revista Brasileira de Biologia $=$ Brazilian Journal of Biology, vol. 63, no. 2, p. 329-343.

PEREIRA, SRS., 2001. Meio fauna perifítica em ambientes lênticos da planície de inundação do Alto Rio Paraná-Brasil. Maringá: Universidade Estadual de Maringá. 44p. Dissertação de Mestrado.

REID, JW., 1985. Chave de identificação e lista de referências bibliograficas para as espécies continentais sulamericanas de vida livre da ordem Cyclopoida (Crustacea, Copepoda). Boletim de Zoologia, vol. 9, p. 17-143.

ROBERTSON, BA. and HARDY, ER., 1984. Zooplankton of Amazonian lakes and Rivers. In SIOLI, H. (Ed.). The Amazon: limnology and landscape ecology of a might tropical river and its basin. Dordrecht: Junk Publishers. p. 337-352.

ROCHA, PC., 2002. Dinâmica dos canais no sistema rioplanície fluvial do alto rio Paraná, nas proximidades de Porto 
Rico-PR. Maringá: Universidade Estadual de Maringá. 169p. Tese de Doutorado.

RODRIGUES, L. and BICUDO, DC., 2004. Periphytic algae. In THOMAZ, SM., AGOSTINHO, AA. and HAHN, NS. (Eds.). The Upper Paraná River and its floodplain: physical aspects, ecology and conservation. Leiden: Backhuys Publishers. p. $125-143$.

RODRIGUES, LC., TRAIN, S., BOVO-SCOMPARIN, VM., JATI, S., BORSALLI, CCJ. and MARENGONI, E., 2009. Interannual variability of phytoplankton in the main Rivers of upper Paraná River floodplain, Brazil: influence of upstream reservoirs. Revista Brasileira de Biologia = Brazilian Journal of Biology, vol. 69, no. (2 suppl), p. 501-516.

SANTOS-WISNIEWSKI, MJ., ROCHA, O., GÜNTZEL, AM. and MATSUMURA-TUNDISI, T., 2002. Cladocera Chydoridae of high altitude water bodies (Serra da Mantiqueira), in Brazil. Revista Brasileira de Biologia = Brazilian Journal of Biology, vol. 62 , no. 4a, p. 681-687.

SEGERS, H., 1995. Rotifera: the Lecanidae (Monogonta). The Hague: SPB Academic. 226p. Guides to the identification of the micro invertebrates of the continental water of the world. Vol. 6 .

SOKAL, RR. and ROHLF, RJ., 1981. Biometry. 2 ed. New York: W. H. Freeman and Company. 859p..

STATSOFT INCORPORATION, 2005. Statistica. Tulsa: STATSOFT INC.

THOMAZ, SM., BINI, LM. and BOZELLI, RL., 2007. Floods increase similarity among aquatic habitats in river-floodplain systems. Hydrobiologia, vol. 579, no. 1, p. 1- 13.

THOMAZ, SM., PAGIORO, TA., BINI, LM., ROBERTO, MC. and ROCHA, RRA., 2004. Limnology of the Upper Paraná Floodplain habitats: patterns of spatio-temporal variations and influence of the water levels. In AGOSTINHO, AA., RODRIGUES, L., GOMES, LC., THOMAZ, SM. and MIRANDA, LE. (Eds.). Structure and functioning of the Paraná River and its floodplain. Maringá: Eduem. p. 37-42.

TOCKNER, K., SCHIEMER, F. and WARD, JV., 1998. Conservation by restoration: the management concept for a river-floodplain system on the Danube River in Austria. Aquatic
Conservation: Marine and Freshwater Ecosystems, vol. 8, no. 1, p. 71-86.

TRAIN, S. and RODRIGUES, LC., 2004. Phytoplankton assemblages. In THOMAZ, SM., AGOSTINHO, AA. and HAHN, NS. (Eds.). The Upper Paraná River and its floodplain: physical aspects, ecology and conservation. Leiden: Backhuys Publishers. p. 103-124.

VASQUEZ, E. and REY, J., 1989. A longitudinal study of zooplankton along the lower Orinoco river and its Delta (Venezuela). Annales de Limnologie, vol. 28, no. 1, p. 3-18.

VELHO, LFM. and LANSAC-TÔHA, FA., 1996. Testate amoebae (Rhizopodea-Sarcodina) from zooplankton of the high Paraná river floodplain, state of Mato Grosso do Sul, Brazil: II. Family Difflugidae. Studies and Neotropical Fauna \& Environment, vol. 31, no. 3, p. 174-192.

VELHO, LFM., LANSAC-TÔHA, FA. and BINI, LM., 2003. Influence of environmental heterogenity on the structure of testate amoebae (Protozoa, Rhizopoda) assemblages in the plankton of the Paraná river floodplain, Brazil. International Review of Hidrobiology, vol. 88, no. 2, p. 154-166.

VELHO, LFM., LANSAC-TÔHA, FA. and SERAFIM JR., M., 1996. Testate amoebae (Rhizopodea-Sarcodina) from zooplankton of the high Paraná river floodplain, State of Mato Grosso do Sul, Brazil: I. Families Arcellidae and Centropyxidae. Studies and Neotropical Fauna \& Environment, vol. 31, no. 1, p. 135-150.

VUCETICH, MC., 1973. Estudio de tecamebianos argentinos, en especial los del dominio pampasico. Revista del Museo La Plata, vol. 118 , no. 11 , p. $287-322$.

WARD, JV. and TOCKNER, K., 2001. Biodiversity: toward a unifying theme for river ecology. Freshwater Biology, vol. 46, no. 6 , p. $807-819$.

WARD, JV., TOCKNER, K. and SCHIEMER, F., 1999. Biodiversity of floodplain river ecosystems: ecotones and connectivity. Regulated Rivers: Research and Management, vol. 15, no. 1-3, p. 125-139.

ZALOCAR De DOMITROVIC, Y., POI De NEIFF, ASG. and CASCO, SL., 2007. Abundance and diversity of phytoplankton in the Paraná River (Argentina) $220 \mathrm{~km}$ downstream of the Yacyretá reservoir. Revista Brasileira de Biologia = Brazilian Journal of Biology, vol. 67, no. 1, p. 53-63. 